\title{
NASA head bows out after a record run
}

William Triplett, Washington

Dan Goldin has announced his departure from NASA, ending what observers say was a stormy but ultimately successful stint as administrator of the US space agency.

The 61-year-old Bronx-born aerospace engineer revealed on 17 October that he will leave next month. Goldin received plenty of criticism during his record nine-and-a-halfyear tenure. But he provided clear vision and immensely energetic leadership at a difficult time for NASA, and the agency's scientists and engineers will now be wondering who will fill his shoes.

Goldin will go down as "the greatest administrator NASA ever had", predicts John Pike, former head of space policy at the Federation of American Scientists and an erstwhile critic of both NASA and its leadership; he now runs the website GlobalSecurity.org.

When Goldin accepted the job of NASA administrator from then-President George Bush in early 1992, he was general manager of TRW, an Ohio-based aerospace and technology contractor. At that time, the agency was still suffering from the aftermath of the 1986 Challenger space-shuttle disaster.

"When Goldin took over, NASA was saddled with problems," says John Logsdon, director of the Space Policy Institute at George Washington University in Washington DC. "He didn't solve all of them, but he did give NASA a strategic vision it badly needed, as well as placing an overall emphasis on cutting-edge technology."

"He was the right man at the right time," says Bradford Parkinson, an aeronautics engineer at Stanford University in California and, until six months ago, chairman of the NASA Advisory Council. "He was an agent of change and NASA needed that because it was a relatively bloated bureaucracy. Since he has a strong sense of himself, he did things others probably couldn't have

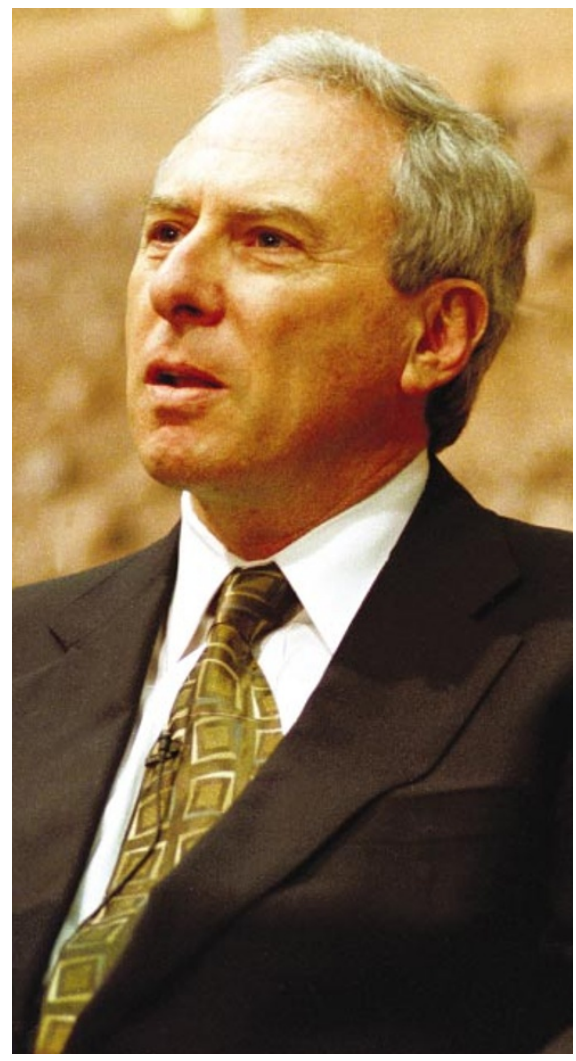

Boldly going: departing administrator Dan Goldin brought vision and energy to his role.

done. But he also angered a lot of people."

With little prospect of obtaining increases in NASA's annual budget — which remained stuck at around $\$ 14$ billion throughout his tenure - Goldin reduced the agency's direct workforce from some 25,000 to 18,500 . He admitted to Congress last year that this reduction was probably too steep.

Meanwhile, the management philosophy he introduced for saving money "faster, better, cheaper" missions - generated complaints that NASA's work was being dangerously underfunded. Critics blamed this approach for the loss in 1999 of two probes to Mars.

"A lot of people said 'faster, better, cheaper' was flawed," says Parkinson. "But it wasn't. Rather, it was new thinking, which meant it was bound to have some breakage." Parkinson believes not only that the philosophy is sound, but also that it will prove to be one of Goldin's enduring contributions to the space programme.

Goldin's other memorial may be the survival, albeit in curtailed form, of the International Space Station project. In 1993, the project came within one vote of elimination in the House of Representatives. But Goldin, working closely with vice-president $\mathrm{Al}$ Gore, brought Russia in and ensured the project's survival.

The station currently faces fresh cost overruns of $\$ 5$ billion, and a report due next month is expected to criticize strongly NASA's management of the project. But Logsdon predicts that the report will concentrate its fire on the Johnson Space Center in Texas, and that Goldin will ultimately be remembered as the man who kept the project alive.

The toughest challenges facing Goldin's successor will include getting space-station costs under control and developing a replacement vehicle for the space shuttle. The aftermath of the 11 September terrorist attacks is likely to intensify pressure on NASA's budget. "The agency was a low priority for this administration before the attacks," says Pike. "It is now a very low priority."

"NASA still needs to sell itself to Congress and to the public," says Parkinson, "but on substance, not stunts. The right leader say, someone slightly more benevolent should be able to take the agency to the next step." Logsdon concurs, saying that the agency still needs "a reformer and consolidator" to head it, but that it should be someone "a little calmer" than Goldin.

\section{Faculty concerns cost university venture-capital funds}

\section{Rex Dalton, San Diego}

A proposal for venture-capital funding of research projects at the University of California, San Francisco (UCSF), has been cancelled after an investment agency withdrew its offer of $\$ 10$ million to support it.

The UCSF had planned to use the money from the California Public Employees' Retirement System (CalPERS) to award grants of up to $\$ 500,000$ to promising research projects to develop drugs or technologies (see Nature 413,
95; 2001). Burrill, a venture-capital firm in San Francisco, was going to manage the fund.

But earlier this month, CalPERS officials said they were withdrawing their investment offer. According to Regis Kelly, UCSF's executive vicechancellor, the withdrawal was linked to concerns raised by UCSF faculty about the programme's potential impact on the university's academic mission. CalPERS officials declined to discuss the decision.
"We are absolutely disappointed," Kelly says. Attempts will be made to address faculty concerns for future ventures, he adds, saying: "We are still interested in setting up a similar fund."

Endocrinologist Daniel Bikle, chair of UCSF's academic senate, who complained that faculty leaders weren't appropriately included in the negotiations with Burrill, says he too is disappointed. But he adds: "We are not a commercial enterprise. Things have to be done without jeopardizing the academic mission.” 